\title{
Adjustment of growth models in broiler chickens
}

\author{
Leandro Félix Demuner ${ }^{(1)}$, Diana Suckeveris ${ }^{(2)}$, Julian Andrés Muñoz ${ }^{(1)}$, \\ Vinicius Camargo Caetano(1), Cesar Gonçalves de Lima ${ }^{(1)}$, \\ Daniel Emygdio de Faria Filho ${ }^{(1)}$ and Douglas Emygdio de Faria ${ }^{(1)}$
}

\begin{abstract}
(1)Universidade de São Paulo (USP), Faculdade de Zootecnia e Engenharia de Alimentos, Avenida Duque de Caxias Norte, no 225, CEP 13635-900 Pirassununga, SP, Brazil. E-mail: leodemuner@usp.br, julianmunoz@usp.br, vinicius.usp.email@gmail.com, cegdlima@usp.br, fariafilho@usp.br, defaria@usp.br (2)USP, Escola Superior de Agricultura Luiz de Queiroz, Avenida Pádua Dias, no 11, CEP 13418-900 Piracicaba, SP, Brazil. E-mail: diana.usp@usp.br
\end{abstract}

Abstract-The objective of this work was to investigate adjustments of the Gompertz, Logistic, von Bertalanffy, and Richards growth models, in male and female chickens of the Cobb 500, Ross 308, and Hubbard Flex lines. Initially, 1,800 chickens were randomly housed in 36 pens, with six replicates per lineage and sex, fed ad libitum with feed according to gender, and bred until 56 days of age. Average weekly body weight for each line and sex was used to estimate model parameters using the ordinary least squares, weighted by the inverse variance of the body weight and weighted with a first-order autocorrelated error structure. Weighted models and weighted autocorrelated error models showed different parameter values when compared with the unweighted models, modifying the inflection point of the curve and according to the adjusted coefficient of determination, and the standard deviation of the residue and Akaike information criteria exhibited optimal adjustments. Among the models studied, the Richards and the Gompertz models had the best adjustments in all situations, with more realistic parameter estimates. However, the weighted Richards model, with or without ponderation with the autoregressive first order model AR (1), exhibited the best adjustments in females and males, respectively.

Index terms: autocorrelated errors, autoregressive model, poultry science, homogeneity of variance, mathematical model, weighting structures.

\section{Ajuste de modelos de crescimento em frangos de corte}

Resumo - O objetivo deste trabalho foi investigar os ajustes dos modelos de crescimento Gompertz, Logístico, von Bertalanffy e Richards em frangos fêmeas e machos das linhagens Cobb 500, Ross 308 e Hubbard Flex. Foram inicialmente utilizados 1.800 frangos, alojados aleatoriamente em 36 unidades experimentais, com seis repetições por linhagem e sexo, alimentados à vontade com ração, de acordo com o gênero, e criados até 56 dias de idade. A partir do peso vivo médio semanal de cada linhagem e sexo, realizou-se a estimação dos parâmetros dos modelos, por meio dos mínimos quadrados ordinários, ponderados pelo inverso da variância do peso e ponderados com estrutura de erros autocorrelacionados de primeira ordem. Modelos ponderados e modelos ponderados com autocorrelação apresentaram valores diferentes dos parâmetros comparados aos modelos não ponderados, mudando o ponto de inflexão da curva e de acordo com o coeficiente de determinação ajustado, e o desvio padrão do resíduo e os critérios de informação de Akaike apresentaram os melhores ajustes. Entre os modelos estudados, os de Richards e Gompertz resultaram nos melhores ajustes em todas as situações, com as estimativas mais reais dos parâmetros. Porém, o modelo ponderado de Richards, com ou sem ponderação com o modelo autorregressivo de primeira ordem AR (1), apresentou os melhores ajustes em fêmeas e machos, respectivamente.

Termos para indexação: erros autocorrelacionados, modelo autorregressivo, avicultura, homogeneidade da variância, modelos matemáticos, estruturas de ponderação.

\section{Introduction}

The current lineages of broiler chickens are a result of successful selection programs to achieve rapid growth, improvements in body conformation, and a consequent reduction in animal slaughter age (Zuidhof, 2014). An essential element to obtain these results is related to the prediction of the potential 
performance of broiler chickens by adjusting growth curves. These curves arise from mathematical models that synthesize the development of the animal, in three or four parameters, evaluating the responses of the treatments over time, identifying the younger and heavier animals in a given population (Freitas, 2005).

Therefore, studying the selection of the optimal function for growth modeling is an essential step in the elaboration of production models. According to Thornley \& France (2007), the most applied curves for bird development are Brody, Logistic, Gompertz, and von Bertalanffy; all of which are special cases of Richard's curve (Mohammed, 2015).

Modeling in animal production has a fundamental role in helping to maximize the system by producing high-precision estimates. This estimation depends on the non violation of statistical assumptions and can produce imprecise results, especially in cases with few samples (Mazucheli et al., 2011).

When studying animal growth, the heterogeneity of variances may occur for weight in function of animal age due to the differences found between weightings. Lower variation is observed in the initial phase of the animal's life, increasing with age due to cumulative effects during animal development (Mazucheli et al., 2011; Silva et al., 2011; Tholon et al., 2012). In addition to the different time variances, these repeated measures may be correlated with dependent residues between the observed ages (Aggrey, 2009; Harring \& Blozis, 2014).

The objective of this work was to investigate adjustments of the Gompertz, Logistic, von Bertalanffy, and Richards growth models, in male and female chickens of the Cobb 500, Ross 308, and Hubbard Flex lines.

\section{Materials and Methods}

The experiment was conducted according to Brazilian guidelines, based on the Federal Law No. 11,794 of October 8, 2008 (Brasil, 2008), and approved by the ethics committee on animal use (Ceua), process No. 14.1.148.74.7. The work was carried out in the poultry laboratory of the Department of Animal Sciences of Faculdade de Zootecnia e Engenharia de Alimentos of Universidade de São Paulo.

The eggs used in the experiment were purchased from a commercial flock of different batches of 4050 week-old Cobb 500 (Cobb), Ross 308 (Ross), and
Hubbard Flex (Hubbard) broiler breeders and were sent to an industrial hatchery. Initially, 1,800 oneday-old chicks were used, 300 of each lineage and sex. The animals were vaccinated for Marek's disease, separated by gender in the hatchery, and vaccinated via intraocular route against the Newcastle and Gumboro diseases at seven days of age.

The experiment began in a $5 \times 32-\mathrm{m}$ experimental aviary with a concrete floor, with 2.5 -m ceiling height, containing two identical rooms with 18 boxes each, which measured $2.47 \mathrm{~m}^{2}$. Fifty one-day-old chicks were housed in each box, distributed in six treatments: male Cobb; female Cobb; male Ross; female Ross; male Hubbard; female Hubbard, using a completely randomized design, containing six replicates per treatment, totaling 36 experimental units (boxes).

Wood shaving beddings were used, as well as nipple drinkers and tubular feeders, according to the different stages of rearing and number of animals. Regarding heating for the birds in the pre-initial phase of development, infrared lamps $(250 \mathrm{~W})$ and gas bells were installed in the corridors. The adopted lighting program was of 23 hours of light +1 hour of dark, from the second day of life of the chicks, using a timer. The daily air temperature and relative humidity were registered using a Hobo data logger (Onset Computer Corporation, Bourne, MA, USA), which recorded mean \pm standard deviation of temperature values of $25.02 \pm 3.74^{\circ} \mathrm{C}$ and relative air humidity of $70.94 \pm 12.65 \%$.

Animal diets were formulated with corn and soybean meal in alingment with the recommendations for superior performance of female and male broiler chickens, as proposed by Rostagno (2011). The diets were provided in the following phases: pre-initial, from 1 to 7 days; initial, from 8 to 21 days; growth I, from 22 to 35 days; growth II, from 36 to 42 days; and final, from 43 to 56 days (Table 1).

In order to obtain body weight (BW) for growth curve adjustment (Table 2), the birds of each box (experimental unit) were weighed weekly, and the mortalities (discard + natural death) and weights of buckets and leftover feed from the feeder were registered for optimal control of the consumption of feed, which was offered freely throughout the experiment.

In addition to $\mathrm{BW}$, other variables were estimated regarding line and sex. Therefore, weekly sampling of each box, with five average weight $( \pm 5 \%)$ birds per 
Table 1. Composition percentage and calculated values for the broiler chicken experimental diets.

\begin{tabular}{|c|c|c|c|c|c|c|c|c|c|c|}
\hline \multirow[t]{2}{*}{$\begin{array}{l}\text { Ingredient } \\
(\%)\end{array}$} & \multicolumn{2}{|c|}{$\begin{array}{l}\text { Pre-initial } \\
\text { (1-7 days) }\end{array}$} & \multicolumn{2}{|c|}{$\begin{array}{c}\text { Initial } \\
\text { (8-21 days) }\end{array}$} & \multicolumn{2}{|c|}{$\begin{array}{c}\text { Growth I } \\
\text { (22-35 days) }\end{array}$} & \multicolumn{2}{|c|}{$\begin{array}{l}\text { Growth II } \\
\text { (36-42 days) }\end{array}$} & \multicolumn{2}{|c|}{$\begin{array}{c}\text { Final } \\
\text { (43-56 days) }\end{array}$} \\
\hline & Male & Female & Male & Female & Male & Female & Male & Female & Male & Female \\
\hline Corn & 53.59 & 55.09 & 57.62 & 56.13 & 59.15 & 61.45 & 63.44 & 65.63 & 65.31 & 67.29 \\
\hline Soybean meal & 38.94 & 37.58 & 34.90 & 36.07 & 32.49 & 31.05 & 28.61 & 27.41 & 26.57 & 25.70 \\
\hline Soybean oil & 2.903 & 2.639 & 3.441 & 3.723 & 4.622 & 4.140 & 4.522 & 4.072 & 4.900 & 4.457 \\
\hline Dicalcium phosphate & 1.904 & 1.915 & 1.539 & 1.557 & 1.335 & 1.172 & 1.124 & 1.084 & 1.018 & 0.806 \\
\hline Calcitic limestone & 0.911 & 0.911 & 0.935 & 0.944 & 0.888 & 0.877 & 0.794 & 0.625 & 0.745 & 0.659 \\
\hline Common salt & 0.508 & 0.507 & 0.457 & 0.483 & 0.458 & 0.445 & 0.445 & 0.419 & 0.432 & 0.407 \\
\hline L-Lysine HCL & 0.286 & 0.349 & 0.252 & 0.237 & 0.237 & 0.184 & 0.264 & 0.134 & 0.257 & 0.095 \\
\hline Methionine (MHA) & 0.426 & 0.453 & 0.360 & 0.364 & 0.342 & 0.230 & 0.318 & 0.215 & 0.291 & 0.171 \\
\hline L-Threonine & 0.116 & 0.146 & 0.085 & 0.081 & 0.072 & 0.037 & 0.076 & 0.000 & 0.067 & 0.000 \\
\hline Supplement $t^{(1)}$ & 0.400 & 0.400 & 0.400 & 0.400 & 0.400 & 0.400 & 0.400 & 0.400 & 0.400 & 0.400 \\
\hline Antioxidant ${ }^{(2)}$ & 0.013 & 0.013 & 0.013 & 0.013 & 0.013 & 0.013 & 0.013 & 0.013 & 0.013 & 0.013 \\
\hline Total & 100 & 100 & 100 & 100 & 100 & 100 & 100 & 100 & 100 & 100 \\
\hline \multicolumn{11}{|l|}{ Energy and nutrients (\%) } \\
\hline $\operatorname{ME}\left(\mathrm{kcal} \mathrm{kg}^{-1}\right)$ & 2,960 & 2,960 & 3,050 & 3,050 & 3,150 & 3,150 & 3,200 & 3,200 & 3,250 & 3,250 \\
\hline PB & 22.40 & 22.00 & 21.20 & 20.80 & 19.80 & 19.20 & 18.40 & 17.80 & 17.60 & 17.10 \\
\hline Dig. lysine & 1.324 & 1.341 & 1.217 & 1.201 & 1.131 & 1.057 & 1.060 & 0.933 & 1.006 & 0.862 \\
\hline Dig. methionin + cystine & 0.953 & 0.965 & 0.876 & 0.864 & 0.826 & 0.722 & 0.774 & 0.681 & 0.734 & 0.629 \\
\hline Dig. methionine & 0.652 & 0.670 & 0.588 & 0.581 & 0.555 & 0.456 & 0.519 & 0.430 & 0.489 & 0.386 \\
\hline Dig. threonine & 0.861 & 0.871 & 0.791 & 0.780 & 0.735 & 0.687 & 0.689 & 0.608 & 0.654 & 0.585 \\
\hline Dig. tryptophan & 0.253 & 0.246 & 0.237 & 0.231 & 0.218 & 0.211 & 0.198 & 0.192 & 0.187 & 0.183 \\
\hline Dig. arginine & 1.417 & 1.379 & 1.334 & 1.302 & 1.231 & 1.193 & 1.226 & 1.092 & 1.065 & 1.044 \\
\hline Dig. valine & 0.944 & 0.922 & 0.896 & 0.878 & 0.835 & 0.815 & 0.773 & 0.757 & 0.739 & 0.728 \\
\hline Dig. leucine & 1.725 & 1.695 & 1.656 & 1.632 & 1.569 & 1.544 & 1.484 & 1.465 & 1.435 & 1.426 \\
\hline Dig. isoleucine & 0.876 & 0.854 & 0.828 & 0.808 & 0.766 & 0.744 & 0.702 & 0.684 & 0.667 & 0.655 \\
\hline Calcium & 0.920 & 0.920 & 0.841 & 0.831 & 0.758 & 0.711 & 0.663 & 0.587 & 0.614 & 0.528 \\
\hline Available phosphorus & 0.470 & 0.470 & 0.401 & 0.396 & 0.354 & 0.322 & 0.309 & 0.274 & 0.286 & 0.246 \\
\hline Potassium & 0.868 & 0.848 & 0.823 & 0.806 & 0.766 & 0.747 & 0.708 & 0.692 & 0.676 & 0.667 \\
\hline Sodium & 0.220 & 0.220 & 0.210 & 0.200 & 0.200 & 0.195 & 0.195 & 0.185 & 0.190 & 0.180 \\
\hline Chlorine & 0.354 & 0.354 & 0.339 & 0.325 & 0.325 & 0.317 & 0.318 & 0.303 & 0.310 & 0.296 \\
\hline
\end{tabular}

(1)Vitamin/mineral premix: pre-initial diet - 2,000,000 IU kg${ }^{-1}$ vitamin A (min.), 600,000 IU kg-1 vitamin D3 (min.), 3,000 IU kg-1 vitamin E (min.), 500 mg kg-1 vitamin K3 (min.), $600 \mathrm{mg} \mathrm{kg}^{-1}$ vitamin B1 (min.), 1,500 mg kg-1 vitamin B2 (min.), 1,000 mg kg-1 vitamin B6 (min.), 3,500 mcg kg-1 vitamin B12 (min.), $10 \mathrm{~g} \mathrm{~kg}^{-1}$ niacin (min.), 3,750 $\mathrm{mg} \mathrm{kg}^{-1}$ pantothenic acid (min.), $250 \mathrm{mg} \mathrm{kg}^{-1}$ folic acid (min.), 86,600 $\mathrm{g} \mathrm{kg}^{-1} \mathrm{choline}^{(\mathrm{min}}$.), 12,500 $\mathrm{g} \mathrm{kg}-1$ iron (min.), 17,500 $\mathrm{g} \mathrm{kg} \mathrm{g}^{-1}$ manganese (min.), 12,500 $\mathrm{g} \mathrm{kg}^{-1}$ zinc (min.), 24,950 $\mathrm{g} \mathrm{kg}^{-1}$ copper (min.), $300 \mathrm{mg} \mathrm{kg}^{-1}$ iodine (min.), $50 \mathrm{mg} \mathrm{kg}^{-1}$ selenium (min.), and 3,750 mg $\mathrm{kg}^{-1}$ virginamycine; initial diet - 1,750,000.00 IU kg-1 vitamin A (min.), 550,000.00 IU kg-1 vitamin D3 (min.), 2,750.00 IU kg ${ }^{-1}$ vitamin E (min.), 400.00 mg kg-1 vitamin K3 (min.), $500.00 \mathrm{mg} \mathrm{kg}^{-1}$ vitamin B1 (min.), 1,250.00 mg kg-1 vitamin B2 (min.), $750.00 \mathrm{mg} \mathrm{kg}^{-1}$ vitamin B6 (min.), 3,000.00 mcg kg vitamin B12 (min.), 8,750.00 mg kg-1 niacin (min.), 3,250.00 $\mathrm{mg} \mathrm{kg}^{-1}$ pantothenic acid (min.), $200.00 \mathrm{mg} \mathrm{kg}^{-1}$ folic acid (min.), $82.01 \mathrm{~g} \mathrm{~kg}^{-1} \mathrm{choline}$ (min.), $12.50 \mathrm{~g} \mathrm{~kg}^{-1}$ iron (min.), $17.50 \mathrm{~g} \mathrm{~kg}^{-1}$ manganese (min.), $12.50 \mathrm{~g} \mathrm{~kg}^{-1}$ zinc (min.), $24.95 \mathrm{~g} \mathrm{~kg}^{-1}$ copper (min.), $300.00 \mathrm{mg} \mathrm{kg}^{-1}$ iodine (min.), $50.00 \mathrm{mg} \mathrm{kg}{ }^{-1}$ selenium (min.), $25.00 \mathrm{~g} \mathrm{~kg}^{-1}$ monensin, and 7,500.00 mg kg-1 halquinol; growth diet - 1,500,000 IU kg -1 vitamin A (min.), (min.) $500,000 \mathrm{IU} \mathrm{kg}{ }^{-1}$ vitamin D3, 2,500 IU kg ${ }^{-1}$ vitamin E (min.), $400 \mathrm{mg} \mathrm{kg}^{-1}$ vitamin K3 (min.), $350 \mathrm{mg} \mathrm{kg}^{-1}$ vitamin B1 (min.), 1,000 mg kg vitamin B2 (min.), $500 \mathrm{mg} \mathrm{kg}{ }^{-1}$ vitamin B6 (min.), 2,500 mcg kg-1 vitamin B12 (min.), 7,500 mg kg-1 niacin (min.), 2,750 mg kg-1 pantothenic acid (min.), $150 \mathrm{mg} \mathrm{kg}^{-1}$ folic acid (min.), $60,400 \mathrm{~g}$ $\mathrm{kg}^{-1}$ choline (min.), 24,950 $\mathrm{g} \mathrm{kg}^{-1}$ copper (min.), 12,500 $\mathrm{g} \mathrm{kg}^{-1}$ iron (min.), 17,500 $\mathrm{g} \mathrm{kg}^{-1}$ manganese (min.), $12,500 \mathrm{~g} \mathrm{~kg}^{-1} \mathrm{zinc}$ (min.), $300 \mathrm{mg} \mathrm{kg}-1$ iodine (min.), $50 \mathrm{mg} \mathrm{kg}^{-1}$ selenium (min.), 7,500 mg kg-1 halquinol, and $15 \mathrm{~g} \mathrm{~kg}^{-1}$ salinomycin; and final diet - 1,250,000 IU kg -1 vitamin A (min.), $250,000 \mathrm{IU}$ $\mathrm{kg}^{-1}$ vitamin D3 (min.), 2,000 IU kg-1 vitamin E (min.), $400 \mathrm{mg} \mathrm{kg}^{-1}$ vitamin K3 (min.), $500 \mathrm{mg} \mathrm{kg}^{-1}$ vitamin B2 (min.), 1,250 mcg kg ${ }^{-1}$ vitamin B12 (min.), 5,000 mg kg ${ }^{-1}$ niacin (min.), 2,250 mg kg-1 pantothenic acid (min.), 31,900 $\mathrm{g} \mathrm{kg}^{-1}$ cholin (min.), 12,500 $\mathrm{g} \mathrm{kg}^{-1}$ iron (min.), 17,500 g kg-1 manganese (min.), 12,500 zinc (min.), 2,000 mg kg $3 \%$ butyl-hydroxytoluene (min.), $11.3 \%$ ethoxyquin (min.), $1 \%$ tert-butyl-hydroquinone (min.), and $4 \%$ citric acid. 
sample, was carried out in the first week (7 days of age) until the fifth week ( 35 days of age); and in the sixth week (42 days of age) until the eighth week (56 days of age), with four birds per sample. However, only live chicken weights were used for model adjustment, and the change in the number of birds in the pen was not significant $(p>0.05)$ regarding weight of line and gender; therefore, the variable bird number was not explored in the models.

The curves were adjusted and analyzed with the Proc Model procedure of SAS, version 9.3 (SAS Institute Inc, Cary, NC, USA), which estimates the parameters of nonlinear models using the Gauss-Newton iterative process (Prado et al., 2013). The BW variance of each age, line, and sex was calculated with the Proc Means also of the SAS software, by applying the inverse of the weight variances as a weighting factor using the "Weight" option of the same software to verify the effect of heteroscedasticity (Silva et al., 2011).

White's test was used to detect heteroscedasticity in the models, testing the equality of random error variance. Moreover, Durbin-Watson's (DW) test was used to compare the null hypothesis that the residues are not correlated against the alternative hypothesis that the residues have first order autocorrelation [AR(1)]. The performance of the models that were unweighted (UW), weighted (W), and weighted with AR(1) was assessed according to Motulsky \& Christopoulos (2003) and Prado et al. (2013), using the following equations for the adjusted coefficient of determination $\left(\mathrm{R}_{\text {adjusted }}^{2}\right)$, the standard deviation of the residue (SDR), and the corrected Akaike's information criterion (AICc), respectively:

$$
\mathrm{R}_{\text {adjusted }}^{2}=1-\left[\frac{(\mathrm{n}-1)\left(1-\mathrm{R}^{2}\right)}{(\mathrm{n}-\mathrm{q})}\right]
$$

in which $\mathrm{R}^{2}=1 \times(\mathrm{SSE} / \mathrm{SSTc})$ is the non-adjusted coefficient of determination and SSE is the sum of the squares of the error; $\mathrm{SSc}$ is the sum of the total squares corrected by $\mathrm{n}$, which is the number of weighings of live chicken; and $\mathrm{q}$ is the number of parameters in the model.

$$
\operatorname{SDR}=\sqrt{\frac{\mathrm{SSE}}{\mathrm{n}-\mathrm{q}}},
$$

in which SSE is the sum of the squares of the error; $n$ is the number of weighings of the live chicken; and q is the number of parameters in the model.

$$
\mathrm{AICc}=\mathrm{n} \ln \left(\frac{\mathrm{SQE}}{\mathrm{n}}\right)+2(\mathrm{q}+1)+\frac{2(\mathrm{q}+1)(\mathrm{q}+2)}{\mathrm{n}-(\mathrm{q}+2)},
$$

in which SQE is the sum of the squares of the residue; $\mathrm{n}$ is the number of weighings of live chicken; and $\mathrm{q}$ is the number of parameters in the model.

Akaike's weight corresponds to the calculation of probability

$$
(P)=\frac{\exp ^{(-0,5 \Delta)}}{1+\exp ^{(-0,5 \Delta)}}
$$

used in the selection of the most correct model ( $p>50 \%)$ to be applied, based on the difference between the AICc of the models, $\Delta=\mathrm{AICc}_{\mathrm{b}}-\mathrm{AICc}_{\mathrm{a}}$.

Table 2. Growth functions and inflection points (IP) used in the performed analyses.

\begin{tabular}{lcc}
\hline Growth function $^{(1)}$ & Equations $^{(1)}\left(\mathrm{Y}_{\mathrm{t}}=\right)$ & $\mathrm{IP}\left(\mathrm{Y}_{\mathrm{i}} ; \mathrm{T}_{\mathrm{i}}\right)$ \\
\hline Gompertz & $\mathrm{A} \exp ^{-\mathrm{Bexp}(-\mathrm{KT})}+\varepsilon_{\mathrm{t}}$ & $0.368 \mathrm{~A} ; \ln (\mathrm{B}) / \mathrm{K}$ \\
Logistic & $\mathrm{A}\left(\mathrm{a}+\exp ^{(-\mathrm{KT})}\right)^{-\mathrm{M}}+\varepsilon_{\mathrm{t}}$ & $\mathrm{A}\left(\frac{\mathrm{M}}{\mathrm{M}+1}\right)^{\mathrm{M}} ; \ln (\mathrm{M}) / \mathrm{K}$ \\
von Bertalanffy & $\mathrm{A}\left(1-\mathrm{B}^{-\mathrm{exp}}{ }^{-\mathrm{KT}}\right)^{3}+\varepsilon_{\mathrm{t}}$ & $0.269 \mathrm{~A} ; \ln (3 \mathrm{~B}) / \mathrm{K}$ \\
Richards & $\mathrm{A}\left(1 \pm \mathrm{Bexp}^{(-\mathrm{KT})}\right)^{-1 / \mathrm{N}}+\varepsilon_{\mathrm{t}}$ & $\mathrm{A}(\mathrm{N}+1)^{-1 / \mathrm{N}} ; \frac{-\ln \left(\frac{\mathrm{N}}{\mathrm{B}}\right)}{\mathrm{K}}$ \\
\hline
\end{tabular}

${ }^{(1)}$ Gompertz, Logistic, and von Bertalanffy were adapted from Freitas (2005); while Richards was adapted from Tompić et al. (2011). A, asymptotic final bodyweight; $\mathrm{B}$, integration constant; $\mathrm{K}$, maturity rate; $\mathrm{M},(-1 / \mathrm{n})$, i.e., the parameter that gives the curve its form; and, the residue in time $\mathrm{t}$. 


\section{Results and Discussion}

The mean weekly weights for each line and sex, as well as the mortality observed during the experiment, are shown in Table 3. Despite the weekly removal of birds, the mean body weight was close to the average recorded in the manuals of the respective lines. The accumulated mortality was $6.61 \%$, with higher mortality for males $(4.26 \%)$ than females $(2.35 \%)$.

Model assessment was carried out for each line and gender, regarding unweighted (UW), weighted (W), and AR(1)-weighted structures. The adjustments for the Gompertz and Logistic models are shown in Table 4, and those for the von Bertalanffy and Richards models, in Table 5.

Following the incorporation of the structures in the models, modifications in estimates regarding non-weighted models (traditional) were observed. These changes followed the same pattern between models (Tables 4 and 5), with the exception of the von Bertalanffy model, with regard to: weight at maturity in females $\left(\mathrm{A}_{\text {Gompertz }}=-29.75 \% ; \mathrm{A}_{\text {Logistic }}=-35.54 \%\right.$; $\mathrm{A}_{\text {Bertalanffy }}=42.62 \%$; and $\mathrm{A}_{\text {Richards }}=-44.41 \%$ ) and males $\left(\mathrm{A}_{\text {Gompertz }}=-12.36 \% ; \quad \mathrm{A}_{\text {Logistic }}=-18.88 \% ; \mathrm{A}_{\text {Bertalanffy }}\right.$ $=86.87 \%$; and $\mathrm{A}_{\text {Richards }}=-12.74 \%$ ); the integration constant in females $\left(\mathrm{B}_{\text {Gompertz }}=5.16 \%\right.$; $\mathrm{B}_{\text {Logistic }}=8.25 \%$; $\mathrm{B}_{\text {Bertalanffy }}=0.87 \%$; and $\mathrm{B}_{\text {Richards }}=44.06 \%$ ) and males $\left(\mathrm{B}_{\text {Gompertz }}=4.15 \% ; \mathrm{B}_{\text {Logistic }}=8.59 \% ; \mathrm{B}_{\text {Bertalanfy }}=1.73 \%\right.$; and $\mathrm{B}_{\text {Richards }}=25.86 \%$ ); and the maturity rate in females $\left(\mathrm{K}_{\text {Gompertz }}=32.44 \% ; \mathrm{K}_{\text {Logistic }}=42.56 \% ; \mathrm{K}_{\text {Bertalanffy }}=\right.$ $-19.38 \%$; and $\left.\mathrm{K}_{\text {Richards }}=116.98 \%\right)$ and males $\left(\mathrm{K}_{\text {Gompertz }}\right.$
$=12.78 \% ; \mathrm{K}_{\text {Logistic }}=22.33 \% ; \mathrm{K}_{\text {Bertalanffy }}=-34.66 \%$; and $\mathrm{K}_{\text {Richards }}=24.98 \%$ ).

The traditional Richards model displayed convergence failure for parameters " $\mathrm{B}$ " and " $\mathrm{N}$ " in Hubbard males, corroborating with the observations made by Mota et al. (2015) and Silva et al. (2011). When incorporating the weighting and autocorrelation structures, it was difficult to approximate the values of the additional autocorrelation parameter for Hubbard male and female lines with the Richards model (Table 5), and for Ross and Hubbard male lines with the Gompertz model (Table 4).

According to Prado et al. (2013), parameter estimation using the residues from the autoregressive first order model AR (1) is not efficient, especially when there is positive autocorrelation, as in the present study. Therefore, this may be more of a caution factor in choosing the best model, since the autocorrelation parameter can be canceled.

The values of the parameters in the models with incorporation of AR (1) in relation to the weighted models presented little difference, with the exception of Hubbard females, which exhibited the lowest mean value ( \pm standard error) of "A" using the Gompertz model $(3,548 \pm 327 \mathrm{~g})$ and mainly using the Logistic model $(2,760 \pm 237 \mathrm{~g})$, which was below the final average weight ( \pm standard error) observed at the end of the experiment $(3,742 \pm 49.95 \mathrm{~g})$.

Traditional or structure incorporated Richards and von Bertalanffy models estimated "unreal" values of weight at maturity for the lines and genders (Table 5), similar to what was observed by Mota et al. (2015) and

Table 3. Observed means \pm standard deviation for the number of birds per experimental unit $(\mathrm{N})$ and mortality percentage of Cobb 500, Ross 308, and Hubbard Flex female and male broiler chickens.

\begin{tabular}{|c|c|c|c|c|c|c|c|c|c|c|c|c|}
\hline \multirow{2}{*}{$\begin{array}{l}\text { Age } \\
\text { (days) }\end{array}$} & \multicolumn{6}{|c|}{ Female } & \multicolumn{6}{|c|}{ Male } \\
\hline & $\mathrm{N}$ & Cobb & $\mathrm{N}$ & Ross & $\mathrm{N}$ & Hubbard & $\mathrm{N}$ & Cobb & $\mathrm{N}$ & Ross & $\mathrm{N}$ & Hubbard \\
\hline 0 & 50 & $41.6 \pm 0.5$ & 50 & $42.3 \pm 0.7$ & 50 & $40.7 \pm 0.3$ & 50 & $41.9 \pm 0.4$ & 50 & $42.9 \pm 0.5$ & 50 & $40.9 \pm 0.3$ \\
\hline 7 & 49 & $157.9 \pm 4.8$ & 50 & $172.9 \pm 6.2$ & 50 & $165.9 \pm 3.8$ & 50 & $167.8 \pm 7.1$ & 50 & $168.3 \pm 9.1$ & 50 & $157.8 \pm 7.5$ \\
\hline 14 & 42 & $445.3 \pm 10$ & 44 & $476.0 \pm 11$ & 45 & $446.5 \pm 4.7$ & 43 & $486.7 \pm 24$ & 43 & $478.7 \pm 14$ & 44 & $450.7 \pm 15$ \\
\hline 21 & 37 & $861.0 \pm 16$ & 39 & $917.3 \pm 21$ & 40 & $865.6 \pm 16$ & 38 & $951.7 \pm 27$ & 38 & $973.3 \pm 21$ & 39 & $872.4 \pm 30$ \\
\hline 28 & 32 & $1,352 \pm 22$ & 34 & $1,454 \pm 20$ & 35 & $1,363 \pm 28$ & 33 & $1,556 \pm 37$ & 33 & $1,615 \pm 30$ & 34 & $1,455 \pm 40$ \\
\hline 35 & 27 & $1,876 \pm 31$ & 29 & $2,043 \pm 22$ & 30 & $1,940 \pm 55$ & 28 & $2,219 \pm 36$ & 27 & $2,309 \pm 67$ & 29 & $2,132 \pm 58$ \\
\hline 42 & 22 & $2,422 \pm 66$ & 24 & $2,614 \pm 58$ & 24 & $2,507 \pm 76$ & 23 & $2,901 \pm 92$ & 22 & $3,068 \pm 102$ & 24 & $2,865 \pm 91$ \\
\hline 49 & 18 & $3,063 \pm 84$ & 20 & $3,250 \pm 66$ & 20 & $3,141 \pm 113$ & 19 & $3,612 \pm 123$ & 18 & $3,739 \pm 88$ & 19 & $3,584 \pm 71$ \\
\hline 56 & 13 & $3,618 \pm 94$ & 16 & $3,873 \pm 99$ & 16 & $3,742 \pm 122$ & 14 & $4,252 \pm 108$ & 14 & $4,440 \pm 102$ & 15 & $4,220 \pm 150$ \\
\hline Mortality $^{(1)}(\%)$ & & 1.31 & & 0.41 & & 0.62 & & 1.63 & & 1.68 & & 0.95 \\
\hline
\end{tabular}

${ }^{(1)}$ According to the total number of birds each week, regarding each line and gender, with total sum of the mortality percentage of $6.61 \%$ ( 82 chickens). 
Table 4. Mean estimates of the A, B, K, M, and Ti paremeters, as well as their standard errors (inside the parenthesis), for the unweighted, weighted, and the weighted with autocorrelated error $\left(\Theta_{1}\right)$ Gompertz and Logistic models, regarding body weight measurements in Cobb 500, Ross 308, and Hubbard Flex female and male broiler chickens.

\begin{tabular}{|c|c|c|c|c|c|c|c|c|c|c|c|c|}
\hline \multirow{2}{*}{ Line } & \multicolumn{2}{|c|}{ A } & \multicolumn{2}{|c|}{$\mathrm{B}^{(1)}$} & \multicolumn{2}{|c|}{$\mathrm{K}$} & \multicolumn{2}{|c|}{$\mathrm{M}^{(2)}$} & \multicolumn{2}{|c|}{$\Theta_{1}$} & \multicolumn{2}{|c|}{$\mathrm{Ti}$} \\
\hline & Female & Male & Female & Male & Female & Male & Female & Male & Female & Male & Female & Male \\
\hline & \multicolumn{12}{|c|}{ Unweighted Gompertz } \\
\hline Cobb & $\begin{array}{l}6480 \\
(317)\end{array}$ & $\begin{array}{l}6942 \\
(261) \\
\end{array}$ & $\begin{array}{c}4.428 \\
(0.084)\end{array}$ & $\begin{array}{r}4.667 \\
(0.098)\end{array}$ & $\begin{array}{c}0.0363 \\
(0.0016)\end{array}$ & $\begin{array}{c}0.0402 \\
(0.0015)\end{array}$ & $\sim 1$ & $\sim 1$ & - & - & 40.92 & 38.30 \\
\hline Ross & $\begin{array}{l}6401 \\
(217) \\
\end{array}$ & $\begin{array}{l}6949 \\
(207) \\
\end{array}$ & $\begin{array}{c}4.439 \\
(0.071) \\
\end{array}$ & $\begin{array}{c}4.793 \\
(0.093) \\
\end{array}$ & $\begin{array}{c}0.0386 \\
(0.0013) \\
\end{array}$ & $\begin{array}{c}0.0421 \\
(0.0013) \\
\end{array}$ & $\sim 1$ & $\sim 1$ & - & - & 38.61 & 37.23 \\
\hline Hubbard & $\begin{array}{l}6402 \\
(287) \\
\end{array}$ & $\begin{array}{l}7009 \\
(254)\end{array}$ & $\begin{array}{c}4.498 \\
(0.090) \\
\end{array}$ & $\begin{array}{c}4.890 \\
(0.101)\end{array}$ & $\begin{array}{c}0.0377 \\
(0.0016)\end{array}$ & $\begin{array}{c}0.0405 \\
(0.0014)\end{array}$ & $\sim 1$ & $\sim 1$ & - & - & 39.83 & 39.21 \\
\hline Cobb & $\begin{array}{l}4545 \\
(113) \\
\end{array}$ & $\begin{array}{l}5831 \\
(126) \\
\end{array}$ & $\begin{array}{c}4.692 \\
(0.025) \\
\end{array}$ & $\begin{array}{c}4.935 \\
(0.022) \\
\end{array}$ & $\begin{array}{c}0.0487 \\
(0.0006) \\
\end{array}$ & $\begin{array}{c}\text { Weighted } \\
0.0471 \\
(0.0005) \\
\end{array}$ & $\begin{array}{l}\text { Gompertz } \\
\quad \sim 1\end{array}$ & $\sim 1$ & - & - & 31.72 & 33.88 \\
\hline Ross & $\begin{array}{l}4906 \\
(105)\end{array}$ & $\begin{array}{l}6265 \\
(91)\end{array}$ & $\begin{array}{c}4.743 \\
(0.022)\end{array}$ & $\begin{array}{c}4.984 \\
(0.015)\end{array}$ & $\begin{array}{c}0.0489 \\
(0.0006)\end{array}$ & $\begin{array}{c}0.0466 \\
(0.0003)\end{array}$ & $\sim 1$ & $\sim 1$ & - & - & 31.83 & 34.44 \\
\hline Hubbard & $\begin{array}{l}4561 \\
(102) \\
\end{array}$ & $\begin{array}{l}6215 \\
(124) \\
\end{array}$ & $\begin{array}{c}4.716 \\
(0.022) \\
\end{array}$ & $\begin{array}{c}5.023 \\
(0.020) \\
\end{array}$ & $\begin{array}{c}0.0500 \\
(0.0005) \\
\end{array}$ & $\begin{array}{c}0.0448 \\
(0.0005) \\
\end{array}$ & $\sim 1$ & $\sim 1$ & - & - & 31.01 & 36.01 \\
\hline & \multicolumn{12}{|c|}{ AR (1)-weighted Gompertz } \\
\hline Cobb & $\begin{array}{l}4527 \\
(209) \\
\end{array}$ & $\begin{array}{l}5845 \\
(184) \\
\end{array}$ & $\begin{array}{c}4.693 \\
(0.046) \\
\end{array}$ & $\begin{array}{c}4.936 \\
(0.032) \\
\end{array}$ & $\begin{array}{c}0.0487 \\
(0.0011) \\
\end{array}$ & $\begin{array}{c}0.0470 \\
(0.0008) \\
\end{array}$ & $\sim 1$ & $\sim 1$ & $\begin{array}{c}0.6446 \\
(0.1223) \\
\end{array}$ & $\begin{array}{c}0.3910 \\
(0.1396) \\
\end{array}$ & 31.77 & 33.94 \\
\hline Ross & $\begin{array}{l}5004 \\
(227)\end{array}$ & $\begin{array}{c}6262 \\
(87) \\
\end{array}$ & $\begin{array}{c}4.784 \\
(0.047)\end{array}$ & $\begin{array}{c}4.983 \\
(0.014) \\
\end{array}$ & $\begin{array}{c}0.0483 \\
(0.0012)\end{array}$ & $\begin{array}{c}0.0466 \\
(0.0003)\end{array}$ & $\sim 1$ & $\sim 1$ & $\begin{array}{c}0.7765 \\
(0.1053)\end{array}$ & $\begin{array}{l}-0.067^{\mathrm{ns}} \\
(0.1504)\end{array}$ & 32.41 & 34.43 \\
\hline Hubbard & $\begin{array}{l}3548 \\
(327) \\
\end{array}$ & $\begin{array}{l}6216 \\
(150) \\
\end{array}$ & $\begin{array}{c}4.478 \\
(0.092) \\
\end{array}$ & $\begin{array}{c}5.024 \\
(0.024) \\
\end{array}$ & $\begin{array}{c}0.0535 \\
(0.0019) \\
\end{array}$ & $\begin{array}{c}0.0448 \\
(0.0006) \\
\end{array}$ & $\sim 1$ & $\sim 1$ & $\begin{array}{c}1.0326 \\
(0.0512) \\
\end{array}$ & $\begin{array}{l}0.1960^{\text {ns }} \\
(0.1445)\end{array}$ & 28.04 & 36.01 \\
\hline & \multicolumn{12}{|c|}{ Unweighted Logistic } \\
\hline Cobb & $\begin{array}{l}5782 \\
(242)\end{array}$ & $\begin{array}{l}6316 \\
(202)\end{array}$ & 1 & 1 & $\begin{array}{c}0.0448 \\
(0.0017)\end{array}$ & $\begin{array}{c}0.0485 \\
(0.0015)\end{array}$ & $\begin{array}{c}5.946 \\
(0.116)\end{array}$ & $\begin{array}{c}6.243 \\
(0.128)\end{array}$ & - & - & 39.83 & 37.71 \\
\hline Ross & $\begin{array}{l}5786 \\
(173)\end{array}$ & $\begin{array}{l}6376 \\
(163)\end{array}$ & 1 & 1 & $\begin{array}{c}0.047 \\
(0.0014)\end{array}$ & $\begin{array}{c}0.0503 \\
(0.0014)\end{array}$ & $\begin{array}{c}5.954 \\
(0.101)\end{array}$ & $\begin{array}{c}6.393 \\
(0.121)\end{array}$ & - & - & 37.91 & 36.85 \\
\hline Hubbard & $\begin{array}{l}5752 \\
(218) \\
\end{array}$ & $\begin{array}{l}6370 \\
(189) \\
\end{array}$ & 1 & 1 & $\begin{array}{c}0.0462 \\
(0.0017)\end{array}$ & $\begin{array}{c}0.0487 \\
(0.0014) \\
\end{array}$ & $\begin{array}{c}6.036 \\
(0.121) \\
\end{array}$ & $\begin{array}{c}6.531 \\
(0.127) \\
\end{array}$ & - & - & 38.93 & 38.53 \\
\hline & \multicolumn{12}{|c|}{ Weighted Logistic } \\
\hline Cobb & $\begin{array}{l}3769 \\
(110)\end{array}$ & $\begin{array}{l}4911 \\
(131)\end{array}$ & 1 & 1 & $\begin{array}{c}0.0642 \\
(0.0010)\end{array}$ & $\begin{array}{c}0.0612 \\
(0.0009)\end{array}$ & $\begin{array}{c}6.488 \\
(0.043)\end{array}$ & $\begin{array}{c}6.868 \\
(0.039)\end{array}$ & - & - & 29.12 & 31.48 \\
\hline Ross & $\begin{array}{l}4182 \\
(116) \\
\end{array}$ & $\begin{array}{l}5333 \\
(97)\end{array}$ & 1 & 1 & $\begin{array}{c}0.0632 \\
(0.0010)\end{array}$ & $\begin{array}{c}0.0606 \\
(0.0006)\end{array}$ & $\begin{array}{c}6.593 \\
(0.044) \\
\end{array}$ & $\begin{array}{c}6.952 \\
(0.028)\end{array}$ & - & - & 29.82 & 32.01 \\
\hline Hubbard & $\begin{array}{l}3725 \\
(113)\end{array}$ & $\begin{array}{l}5159 \\
(120)\end{array}$ & 1 & 1 & $\begin{array}{c}0.0670 \\
(0.0009)\end{array}$ & $\begin{array}{c}0.0588 \\
(0.0007)\end{array}$ & $\begin{array}{c}6.507 \\
(0.044)\end{array}$ & $\begin{array}{c}6.977 \\
(0.034)\end{array}$ & - & - & 27.97 & 33.01 \\
\hline & \multicolumn{12}{|c|}{ AR (1)-weighted Logistic } \\
\hline Cobb & $\begin{array}{l}3682 \\
(230) \\
\end{array}$ & $\begin{array}{l}4932 \\
(258) \\
\end{array}$ & 1 & 1 & $\begin{array}{c}0.0643 \\
(0.0021) \\
\end{array}$ & $\begin{array}{c}0.0611 \\
(0.0017) \\
\end{array}$ & $\begin{array}{c}6.476 \\
(0.092)\end{array}$ & $\begin{array}{c}6.865 \\
(0.076)\end{array}$ & $\begin{array}{c}0.8444 \\
(0.0948)\end{array}$ & $\begin{array}{c}0.7176 \\
(0.1117)\end{array}$ & 29.02 & 31.50 \\
\hline Ross & $\begin{array}{l}4218 \\
(255) \\
\end{array}$ & $\begin{array}{l}5391 \\
(172) \\
\end{array}$ & 1 & 1 & $\begin{array}{c}0.0619 \\
(0.0021)\end{array}$ & $\begin{array}{c}0.0603 \\
(0.0010) \\
\end{array}$ & $\begin{array}{c}6.665 \\
(0.091) \\
\end{array}$ & $\begin{array}{c}6.966 \\
(0.048) \\
\end{array}$ & $\begin{array}{c}0.9386 \\
(0.0742) \\
\end{array}$ & $\begin{array}{c}0.5395 \\
(0.1321) \\
\end{array}$ & 30.66 & 32.16 \\
\hline Hubbard & $\begin{array}{l}2760 \\
(237)\end{array}$ & $\begin{array}{l}5204 \\
(212)\end{array}$ & 1 & 1 & $\begin{array}{c}0.0727 \\
(0.0025)\end{array}$ & $\begin{array}{c}0.0588 \\
(0.0013)\end{array}$ & $\begin{array}{c}6.097 \\
(0.124)\end{array}$ & $\begin{array}{c}6.991 \\
(0.059)\end{array}$ & $\begin{array}{c}1.0456 \\
(0.0414)\end{array}$ & $\begin{array}{c}0.5822 \\
(0.1244)\end{array}$ & 24.85 & 33.09 \\
\hline
\end{tabular}

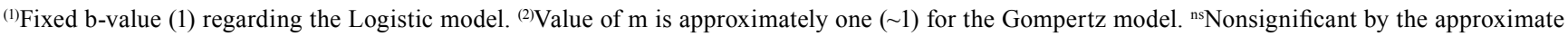
t-test value, at $5 \%$ probability. 
Table 5. Mean estimates of the A, B, K, M, and Ti parameters, as well as their standard errors (inside the parenthesis), for the unweighted, weighted, and weighted with autocorrelated error $\left(\Theta_{1}\right)$ Richards and von Bertalanffy models regarding body weight measurements in Cobb 500, Ross 308, and Hubbard Flex female and male broiler chickens.

\begin{tabular}{|c|c|c|c|c|c|c|c|c|c|c|c|c|}
\hline \multirow{2}{*}{ Line } & \multicolumn{2}{|c|}{ A } & \multicolumn{2}{|c|}{$\mathrm{B}$} & \multicolumn{2}{|c|}{ K } & \multicolumn{2}{|c|}{$\mathrm{M}^{(1)}$} & \multicolumn{2}{|c|}{$\Theta_{1}$} & \multicolumn{2}{|c|}{$\mathrm{T}_{\mathrm{i}}$} \\
\hline & Female & Male & Female & Male & Female & Male & Female & Male & Female & Male & Female & Male \\
\hline & \multicolumn{12}{|c|}{ Unweighted von Bertalanffy } \\
\hline Cobb & $\begin{array}{l}9829 \\
(792)\end{array}$ & $\begin{array}{l}9808 \\
(628)\end{array}$ & $\begin{array}{c}0.844 \\
(0.008)\end{array}$ & $\begin{array}{c}0.871 \\
(0.011)\end{array}$ & $\begin{array}{c}0.0196 \\
(0.0013)\end{array}$ & $\begin{array}{c}0.0229 \\
(0.0013)\end{array}$ & 3 & 3 & - & - & 47.30 & 41.99 \\
\hline Ross & $\begin{array}{l}9151 \\
(456)\end{array}$ & $\begin{array}{l}9511 \\
(480)\end{array}$ & $\begin{array}{c}0.847 \\
(0.007)\end{array}$ & $\begin{array}{c}0.888 \\
(0.011)\end{array}$ & $\begin{array}{c}0.0218 \\
(0.0009)\end{array}$ & $\begin{array}{c}0.0246 \\
(0.0012)\end{array}$ & 3 & 3 & - & - & 42.80 & 39.87 \\
\hline Hubbard & $\begin{array}{l}9468 \\
(720)\end{array}$ & $\begin{array}{l}10146 \\
(705)\end{array}$ & $\begin{array}{c}0.851 \\
(0.009)\end{array}$ & $\begin{array}{c}0.891 \\
(0.012)\end{array}$ & $\begin{array}{c}0.0207 \\
(0.0013)\end{array}$ & $\begin{array}{c}0.0226 \\
(0.0014)\end{array}$ & 3 & 3 & - & - & 45.19 & 43.60 \\
\hline & \multicolumn{12}{|c|}{ Weighted von Bertalanffy } \\
\hline Cobb & $\begin{array}{l}12523 \\
(1070)\end{array}$ & $\begin{array}{l}15944 \\
(1435)\end{array}$ & $\begin{array}{c}0.851 \\
(0.004)\end{array}$ & $\begin{array}{c}0.862 \\
(0.004)\end{array}$ & $\begin{array}{c}0.0170 \\
(0.0008)\end{array}$ & $\begin{array}{c}0.0164 \\
(0.0008)\end{array}$ & 3 & 3 & - & - & 55.13 & 57.96 \\
\hline Ross & $\begin{array}{l}11307 \\
(599)\end{array}$ & $\begin{array}{l}16201 \\
(1197)\end{array}$ & $\begin{array}{c}0.845 \\
(0.003)\end{array}$ & $\begin{array}{c}0.862 \\
(0.003)\end{array}$ & $\begin{array}{c}0.01885 \\
(0.0006)\end{array}$ & $\begin{array}{l}0.01648 \\
(0.0006)\end{array}$ & 3 & 3 & - & - & 49.38 & 57.65 \\
\hline Hubbard & $\begin{array}{c}13740 \\
(911)\end{array}$ & $\begin{array}{l}21018 \\
(1913)\end{array}$ & $\begin{array}{c}0.856 \\
(0.003)\end{array}$ & $\begin{array}{c}0.875 \\
(0.004)\end{array}$ & $\begin{array}{c}0.0164 \\
(0.0005)\end{array}$ & $\begin{array}{c}0.0138 \\
(0.0006)\end{array}$ & 3 & 3 & - & - & 57.62 & 69.79 \\
\hline & \multicolumn{12}{|c|}{ AR (1)-weighted von Bertalanffy } \\
\hline Cobb & $\begin{array}{c}14772 \\
(3006)\end{array}$ & $\begin{array}{l}19352 \\
(4251)\end{array}$ & $\begin{array}{c}0.859 \\
(0.009)\end{array}$ & $\begin{array}{c}0.870 \\
(0.009)\end{array}$ & $\begin{array}{c}0.0155 \\
(0.0016)\end{array}$ & $\begin{array}{c}0.0149 \\
(0.0017)\end{array}$ & 3 & 3 & $\begin{array}{c}0.827 \\
(0.095)\end{array}$ & $\begin{array}{c}0.816 \\
(0.104)\end{array}$ & 61.24 & 64.53 \\
\hline Ross & $\begin{array}{l}15577 \\
(2399)\end{array}$ & $\begin{array}{l}16612 \\
(2400)\end{array}$ & $\begin{array}{c}0.862 \\
(0.007)\end{array}$ & $\begin{array}{c}0.863 \\
(0.007)\end{array}$ & $\begin{array}{c}0.0156 \\
(0.0012)\end{array}$ & $\begin{array}{c}0.0163 \\
(0.0012)\end{array}$ & 3 & 3 & $\begin{array}{c}0.971 \\
(0.061)\end{array}$ & $\begin{array}{c}0.684 \\
(0.116)\end{array}$ & 60.78 & 58.22 \\
\hline Hubbard & $\begin{array}{l}13172 \\
(1801)\end{array}$ & $\begin{array}{l}21224 \\
(3480)\end{array}$ & $\begin{array}{c}0.855 \\
(0.006)\end{array}$ & $\begin{array}{c}0.876 \\
(0.007)\end{array}$ & $\begin{array}{c}0.0167 \\
(0.0011)\end{array}$ & $\begin{array}{c}0.0138 \\
(0.0011)\end{array}$ & 3 & 3 & $\begin{array}{c}0.737 \\
(0.106)\end{array}$ & $\begin{array}{c}0.639 \\
(0.122)\end{array}$ & 56.53 & 70.09 \\
\hline & \multicolumn{12}{|c|}{ Unweighted Richards } \\
\hline Cobb & $\begin{array}{l}13969 \\
(5607)\end{array}$ & $\begin{array}{c}8934 \\
(1386)\end{array}$ & $\begin{array}{l}-0.955 \\
(0.058)\end{array}$ & $\begin{array}{l}-0.783 \\
(0.175)\end{array}$ & $\begin{array}{c}0.0128 \\
(0.0057)\end{array}$ & $\begin{array}{c}0.0263 \\
(0.0059)\end{array}$ & $\begin{array}{l}-0.467 \\
(0.108)\end{array}$ & $\begin{array}{l}-0.268 \\
(0.111)\end{array}$ & - & - & 55.60 & 40.80 \\
\hline Ross & $\begin{array}{l}10377 \\
(1836)\end{array}$ & $\begin{array}{l}8206 \\
(850)\end{array}$ & $\begin{array}{l}-0.914 \\
(0.065)\end{array}$ & $\begin{array}{l}-0.690 \\
(0.199)\end{array}$ & $\begin{array}{c}0.0183 \\
(0.0041)\end{array}$ & $\begin{array}{c}0.0311 \\
(0.0052)\end{array}$ & $\begin{array}{l}-0.401 \\
(0.079)\end{array}$ & $\begin{array}{l}-0.209 \\
(0.095)\end{array}$ & - & - & 44.88 & 38.40 \\
\hline Hubbard & $\begin{array}{c}9889 \\
(2418)\end{array}$ & $\begin{array}{l}7387 \\
(790)\end{array}$ & $\begin{array}{l}-0.876 \\
(0.118)\end{array}$ & $\begin{array}{c}-0.292 \mathrm{~ns} \\
(0.448)\end{array}$ & $\begin{array}{c}0.0196 \\
(0.0061)\end{array}$ & $\begin{array}{c}0.0368 \\
(0.0065)\end{array}$ & $\begin{array}{l}-0.356 \\
(0.115)\end{array}$ & $\begin{array}{c}-0.068^{\mathrm{ns}} \\
(0.118)\end{array}$ & - & - & 45.98 & 39.67 \\
\hline & \multicolumn{12}{|c|}{ Weighted Richards } \\
\hline Cobb & $\begin{array}{l}5569 \\
(381)\end{array}$ & $\begin{array}{l}6816 \\
(364)\end{array}$ & $\begin{array}{l}-0.422 \\
(0.088)\end{array}$ & $\begin{array}{l}-0.372 \\
(0.081)\end{array}$ & $\begin{array}{c}0.0378 \\
(0.0029)\end{array}$ & $\begin{array}{c}0.0385 \\
(0.0023)\end{array}$ & $\begin{array}{l}-0.112 \\
(0.029)\end{array}$ & $\begin{array}{l}-0.091 \\
(0.025)\end{array}$ & - & - & 35.14 & 36.51 \\
\hline Ross & $\begin{array}{l}6495 \\
(316)\end{array}$ & $\begin{array}{l}6822 \\
(277)\end{array}$ & $\begin{array}{l}-0.563 \\
(0.048)\end{array}$ & $\begin{array}{l}-0.247 \\
(0.088)\end{array}$ & $\begin{array}{c}0.0338 \\
(0.0018)\end{array}$ & $\begin{array}{c}0.0414 \\
(0.0021)\end{array}$ & $\begin{array}{l}-0.164 \\
(0.020)\end{array}$ & $\begin{array}{l}-0.056 \\
(0.023)\end{array}$ & - & - & 36.43 & 35.90 \\
\hline Hubbard & $\begin{array}{l}6214 \\
(360)\end{array}$ & $\begin{array}{l}7560 \\
(500)\end{array}$ & $\begin{array}{l}-0.525 \\
(0.052)\end{array}$ & $\begin{array}{l}-0.406 \\
(0.086)\end{array}$ & $\begin{array}{c}0.0345 \\
(0.0021)\end{array}$ & $\begin{array}{c}0.0352 \\
(0.0025)\end{array}$ & $\begin{array}{l}-0.148 \\
(0.020)\end{array}$ & $\begin{array}{l}-0.100 \\
(0.026)\end{array}$ & - & - & 36.64 & 39.78 \\
\hline & \multicolumn{12}{|c|}{ AR (1)-weighted Richards } \\
\hline Cobb & $\begin{array}{l}5578 \\
(614)\end{array}$ & $\begin{array}{l}6821 \\
(448)\end{array}$ & $\begin{array}{l}-0.423 \\
(0.137)\end{array}$ & $\begin{array}{l}-0.371 \\
(0.100)\end{array}$ & $\begin{array}{c}0.0376 \\
(0.0045)\end{array}$ & $\begin{array}{c}0.0384 \\
(0.0029)\end{array}$ & $\begin{array}{l}-0.112 \\
(0.046)\end{array}$ & $\begin{array}{l}-0.091 \\
(0.030)\end{array}$ & $\begin{array}{c}0.525 \\
(0.134)\end{array}$ & $\begin{array}{l}-3.03^{\mathrm{ns}} \\
(0.004)\end{array}$ & 35.26 & 36.54 \\
\hline Ross & $\begin{array}{l}6743 \\
(538)\end{array}$ & $\begin{array}{l}6820 \\
(232)\end{array}$ & $\begin{array}{l}-0.592 \\
(0.070)\end{array}$ & $\begin{array}{l}-0.249 \\
(0.074)\end{array}$ & $\begin{array}{c}0.0325 \\
(0.0028)\end{array}$ & $\begin{array}{c}0.0413 \\
(0.0018)\end{array}$ & $\begin{array}{l}-0.176 \\
(0.031)\end{array}$ & $\begin{array}{l}-0.057 \\
(0.019)\end{array}$ & $\begin{array}{c}0.476 \\
(0.133)\end{array}$ & $\begin{array}{l}-2.98^{\mathrm{ns}} \\
(0.004)\end{array}$ & 37.21 & 35.90 \\
\hline Hubbard & $\begin{array}{l}6261 \\
(462)\end{array}$ & $\begin{array}{l}7561 \\
(506)\end{array}$ & $\begin{array}{l}-0.533 \\
(0.065)\end{array}$ & $\begin{array}{l}-0.406 \\
(0.087)\end{array}$ & $\begin{array}{c}0.0342 \\
(0.0026)\end{array}$ & $\begin{array}{c}0.0353 \\
(0.0026)\end{array}$ & $\begin{array}{l}-0.151 \\
(0.026)\end{array}$ & $\begin{array}{l}-0.100 \\
(0.027)\end{array}$ & $\begin{array}{l}0.249^{\text {ns }} \\
(0.150)\end{array}$ & $\begin{array}{l}0.001^{\mathrm{ns}} \\
(0.150)\end{array}$ & 36.80 & 39.78 \\
\hline
\end{tabular}

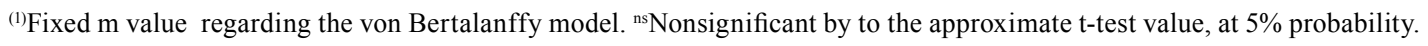


Drumond et al. (2013), while using the traditional von Bertanlaffy model on quails. According to Fitzhugh Jr. (1976), to determine the method of choice of the adjusted growth curve, the model must have an optimum fit of data, retain correct biological interpretation, and present no difficulty in data convergence.

Gbangboche et al. (2008) highlighted that model choice affects parameter estimation, affecting the inflection point (IP) of the curve, which is an important economic indicator in animal production. It is known that the point of the von Bertalanffy model is close to $26.9 \%$ of the value of " $\mathrm{A}$ " and the Gompertz model has an IP of the curve close to $36.8 \%$ of "A". However, the Logistic and Richards models vary according to the "M" $(1 / \mathrm{N})$ of the curve (Table 3$)$.

The variations in model parameters affected the curve inflection day (Ti) due to the strong correlation between them (Eleroğlu et al., 2014), which contributed to greater precocity among females $\left(\mathrm{Ti}_{\text {Gompertz }}=-21.70 \%\right.$; $\mathrm{Ti}_{\text {Logistic }}=-26.47 \%$; and $\left.\mathrm{Ti}_{\text {Richards }}=-24.93 \%\right)$ than males $\left(\mathrm{Ti}_{\text {Gompertz }}=-9.04 \% ; \mathrm{Ti}_{\text {Logistic }}=-14.55 \%\right.$; and $\mathrm{Ti}_{\text {Richards }}=$ $-5.57 \%$ ), when comparing the traditional models to the modified ones. The von Bertanlaffy model was an exception since it exhibited elevated values of "A" and curve IP for females $\left(\mathrm{Ti}_{\text {Bertalanffy }}=26 \%\right)$ and for males $\left(\mathrm{Ti}_{\text {Bertalanfy }}=50.53 \%\right)$, when weighting and autocorrelation were incorporated.

In Table 6 and 7, the values regarding the quality of the adjustments $\left(\mathrm{R}^{2}{ }_{\text {adj }}\right.$, SDR, and AICc) of the models, tests of heteroscedasticity (White test), and the test for error independents (Durbin-Watson test) are shown, according to line and gender.

The adjusted coefficients of determination $\left(\mathrm{R}^{2}{ }_{\text {adj }}\right)$ for the models in the present study were close to one hundred, noting that performance was enhanced when a structure was incorporated. In this case, caution should be taken when evaluating the quality of the adjustment since $\mathrm{R}^{2}$ adj is not a good differentiator in the choice of models, considering that they are high and close (Silva et al., 2011; Drumond et al., 2013). According to Tholon et al. (2012), multicollinearity, in this case, may occur due to the high relationship between the dependent variables of the model, not exhibiting any significance in the regression coefficients.

As shown in Table 7 and 8, the SDR, regarding the weighted and autocorrelation-weighted models, was reduced from 95.88 to $98.36 \%$, in comparison with the unweighted models. This result shows that there was less oscillation in the observed points of weight in relation to the predicted mean when a structure was incorporated into the models.

Lower AICc estimates were verified in weighted models, which were close to those found in the model that was weighted with autocorrelated errors. Therefore, choosing the optimal approach for model adjustment was inconclusive.

Regarding the majority of the studied groups, the traditional models displayed heteroscedasticity and error autocorrelations, according to the White and Durbin-Watson (DW) tests, in Tables 6 and 7, respectively. When weighting was performed without the AR (1) structure, homoscedasticity was observed for all the studied groups using the Richards model, but with positive autocorrelation for Cobb females and males (Table 7). In turn, when combining weighting and AR (1), there was an improvement in the adjustments and error independence using the Gompertz, Logistic, and Richards models, regarding female lines.

In order to avoid causing uncertainty to the researcher regarding the small differences described between the AICc of the models, the weight of AICc was calculated (Prado et al., 2013). Due to optimal adjustments and parameter interpretation, only the weighted and AR (1)-weighted Gompertz and Richards models were compared (Table 8). Between these models, the combined structures were verified as being more correct ( $p>50 \%)$ in the female lines. In turn, regarding the male lines, Cobb chickens were the most accurate ( $>50 \%$ ) only for the AR (1)-weighted Gompertz model, whereas, for Ross and Hubbard chickens, the best performances ( $>50 \%$ ) were observed using the Richards and Gompertz weighted models.

With regard to the outcome of the models, an alternative comparison was carried out (Table 8), this time using the optimum models separately. As a result, the use of the Richards model, weighted with the AR (1) structure, was more adequate for females (Cobb = $81.45 \%$; Ross $=99.99 \%$; Hubbard $=99.84 \%$ ), and the weighted Richards model was more appropriate for males $(\mathrm{Cobb}=93.47 \%$; Ross $=94.74 \%$; Hubbard $=$ 99.08\%).

Mazucheli et al. (2011), in a study on chicken growth using the homoscedastic and heteroscedastic Gompertz model with independent errors, concluded that the weighted model was more appropriate than the unweighted one. The authors verified less weight at maturity and lower standard error, and, thus, greater 
precision regarding the statistical effect and studied factors, as in the current study.

In literature, different conclusions with respect to the adjustment of growth models in birds were reached. Tompić et al. (2011) obtained the best adjustments using the Richards and Gompertz growth models in broilers;
Yang et al. (2006) reported the von Bertalanffy model as the most accurate in Jinghai Yellow chicken; and Eleroğlu et al. (2014) had concluded that the Logistic model the best fit in growth of slow performance chickens. However, despite the variety of existing growth models, one of the most recommended ones

Table 6. Mean adjustment assessment of the unweighted, weighted, and weighted with autocorrelated error Gompertz and Logistic models regarding body weight measurements in Cobb 500, Ross 308, and Hubbard Flex female and male broiler chickens, by way of the adjusted coefficient of determination $\left(\mathrm{R}_{\mathrm{aj}}^{2}\right)$, the standard deviation of the residue (SDR), the corrected Akaike information criteria (AICc), the Durbin-Watson (DW) test, and the White test.

\begin{tabular}{|c|c|c|c|c|c|c|c|c|c|c|c|c|}
\hline \multirow{3}{*}{ Linear } & \multicolumn{2}{|c|}{$\mathrm{R}_{\mathrm{aj}}^{2}$} & \multicolumn{2}{|c|}{ SDR } & \multicolumn{2}{|c|}{$\mathrm{AICc}$} & \multicolumn{4}{|c|}{ DW test } & \multicolumn{2}{|c|}{ White test } \\
\hline & \multirow{2}{*}{ Female } & \multirow{2}{*}{ Male } & \multirow{2}{*}{ Female } & \multirow{2}{*}{ Male } & \multirow{2}{*}{ Female } & \multirow{2}{*}{ Male } & \multicolumn{2}{|c|}{ Female } & \multicolumn{2}{|c|}{ Male } & \multirow{2}{*}{ Female } & \multirow{2}{*}{ Male } \\
\hline & & & & & & & $\mathrm{p}<\mathrm{DW}$ & $\mathrm{p}>\mathrm{DW}$ & $\mathrm{p}<\mathrm{DW}$ & $\mathrm{p}>\mathrm{DW}$ & & \\
\hline \multirow{3}{*}{ Cobb } & \multicolumn{12}{|c|}{ Unweighted Gompertz } \\
\hline & \multirow{2}{*}{99.71} & \multirow{2}{*}{99.77} & & & & & & & & & & $*$ \\
\hline & & & 66.82 & 70.57 & 457.21 & 463.11 & 0.198 & 0.802 & $*$ & 0.998 & 0.095 & $*$ \\
\hline Ross & 9983 & 9984 & 54.58 & 6232 & 43536 & 44968 & & & & & $*$ & * \\
\hline Ross & 99.83 & 99.84 & 54.58 & 62.32 & 435.36 & 449.68 & $* *$ & 1.000 & 0.503 & 0.497 & & \\
\hline & & & & & & & & & & & $*$ & $* *$ \\
\hline Hubbard & 99.73 & 99.80 & 66.52 & 65.00 & 456.73 & 454.23 & 0.151 & 0.849 & 0.664 & 0.336 & $*$ & $* *$ \\
\hline & & & & & & Weighte & ompertz & & & & & \\
\hline Cohb & 9982 & 9986 & & & & 2716 & & & & & & \\
\hline Cobb & 99.82 & 99.86 & 1.749 & 1.246 & 63.77 & 27.16 & $* *$ & 1.000 & $*$ & 0.999 & 0.093 & 0.504 \\
\hline Ross & 9987 & 9991 & 1819 & 1102 & 67.99 & 1391 & & & & & $*$ & 0881 \\
\hline Koss & 99.81 & 99.91 & 1.819 & 1.102 & $6 / .99$ & 13.91 & $* *$ & 1.000 & $* *$ & 1.000 & $*$ & 0.881 \\
\hline Hubbard & 9985 & 9985 & 1739 & 1205 & 63.18 & 2350 & & 0 & & 0 & * & 0094 \\
\hline Huboara & & 99.85 & 1.139 & 1.205 & 03.18 & & $* *$ & 1.000 & $*$ & 0.992 & & \\
\hline & & & & & & (1)-weis & d Gomp & & & & & \\
\hline & & & & & & & & & & & & \\
\hline Cobb & 99.88 & 99.88 & 1.426 & 1.171 & 43.00 & 21.67 & 0.901 & 0.099 & 0.622 & 0.378 & 0.743 & 0.879 \\
\hline Ross & 9993 & 9990 & 1330 & 1.111 & 35.43 & & & & & & & \\
\hline Ross & 99.93 & 99.90 & 1.330 & 1.111 & 35.43 & 16.03 & 0.664 & 0.336 & 0.207 & 0.793 & $*$ & 0.163 \\
\hline Hubbard & 9991 & 9985 & 1371 & 1195 & 38.74 & 2389 & & & & & 0649 & 0495 \\
\hline Hubbard & 99.91 & 99.85 & $1.3 / 1$ & 1.195 & 38.14 & 23.89 & 0.645 & 0.355 & 0.417 & 0.583 & 0.649 & 0.495 \\
\hline & & & & & & Unweigh & Logistic & & & & & \\
\hline Cobb & 99.66 & 99.74 & 72.15 & 75.00 & 465.5 & 469.70 & & & & & 01378 & $*$ \\
\hline & & & & & & 409.10 & 0.045 & 0.955 & $*$ & 1.000 & $0.15 / 8$ & \\
\hline Ross & 99.78 & 99.81 & 61.39 & 66.89 & 448.05 & 45732 & & & & & * & $*$ \\
\hline & & & & & & $45 \% .32$ & $* *$ & 1.000 & 0.158 & 0.842 & & \\
\hline Hubbard & 9969 & 9979 & 70.98 & 66.72 & 463.73 & 45704 & & & & & * & ** \\
\hline & 99.09 & 99.19 & 10.90 & 00.12 & & 451.04 & $*$ & 0.967 & 0.549 & 0.451 & . & \\
\hline & & & & & & Weight & ogistic & & & & & \\
\hline Cobb & 99.64 & 99.71 & 2.46 & 1.83 & 100.73 & 68.41 & & & & & $*$ & $*$ \\
\hline CODD & 99.04 & 99.11 & 2.40 & 1.83 & 100.13 & 08.41 & $* *$ & 1.000 & $* *$ & 1.000 & $*$ & N \\
\hline Ross & 99.68 & 99.79 & 2.83 & 1.65 & 115.68 & 57.77 & & & & & ** & $*$ \\
\hline & & & & & & & $* *$ & 1.000 & $* *$ & 1.000 & & \\
\hline Hubbard & 99.60 & 99.69 & 2.78 & 1.73 & 114.00 & 62.58 & . & & & & $* *$ & * \\
\hline & & & & & & & $* *$ & 1.000 & $* *$ & 1.000 & & \\
\hline & & & & & & (1)-we & ed Logis & & & & & \\
\hline Cobb & 9985 & 9984 & 160 & 137 & 5525 & 3850 & & & & & 0074 & 0103 \\
\hline Cobb & 99.85 & 99.84 & 1.60 & 1.31 & 55.25 & 38.50 & 0.990 & $*$ & 0.865 & 0.135 & $0.0 / 4$ & 0.103 \\
\hline Ross & 99.90 & 99.84 & 1.60 & 1.45 & 55.17 & 44.42 & & & & & $* *$ & 0364 \\
\hline & & 97.04 & & & & $4+.42$ & 0.837 & 0.163 & 0.980 & $*$ & & 0.504 \\
\hline Hubbard & 99.89 & 99.78 & 1.48 & 1.46 & 47.04 & 4539 & & & & & 0.483 & $*$ \\
\hline & & & & & 47.04 & 45.39 & 0.597 & 0.403 & 0.686 & 0.314 & & \\
\hline
\end{tabular}

$*$ and $* *$ Significant at 0.5 and $0.1 \%$ probability, respectively. 
has been the Gompertz model in its traditional form (Freitas, 2005; Mazucheli et al., 2011; Drumond et al., 2013; Mohammed, 2015; Mota et al., 2015).

In the current study, the Gompertz model exhibited optimal interpretation and convergence of estimates in its traditional form, when compared to the traditional Richards model. However, when weighted or weighted with the AR (1) structure, the Richards model displayed superior fit and interpretation of parameter estimates, showing that model selection may vary according to the data and the use of statistical properties.

Table 7. Mean adjustment assessment of the unweighted, weighted, and weighted with autocorrelated error von Bertalanffy and Richards models regarding body weight measurements of Cobb 500, Ross 308, and Hubbard Flex female and male broiler chickens, by way of the adjusted coefficient of determination $\left(\mathrm{R}_{\mathrm{aj}}{ }_{\mathrm{aj}}\right.$ ), the standard deviation of the residue (SDR), the corrected Akaike information criteria (AICc), the Durbin-Watson (DW) test, and the White test.

\begin{tabular}{|c|c|c|c|c|c|c|c|c|c|c|c|c|}
\hline \multirow{3}{*}{ Line } & \multicolumn{2}{|c|}{$\mathrm{R}_{\text {aj }}^{2}(\%)$} & \multicolumn{2}{|c|}{ SDR } & \multicolumn{2}{|c|}{$\mathrm{AICc}$} & \multicolumn{4}{|c|}{ DW test } & \multicolumn{2}{|c|}{ White test } \\
\hline & \multirow{2}{*}{ Female } & \multirow{2}{*}{ Male } & \multirow{2}{*}{ Female } & \multirow{2}{*}{ Male } & \multirow{2}{*}{ Female } & \multirow[b]{2}{*}{ Male } & \multicolumn{2}{|c|}{ Female } & \multicolumn{2}{|c|}{ Male } & \multirow{2}{*}{ Female } & \multirow{2}{*}{ Male } \\
\hline & & & & & & & $\mathrm{p}<\mathrm{DW}$ & $\mathrm{p}>\mathrm{DW}$ & $\mathrm{p}<\mathrm{DW}$ & $\mathrm{p}>\mathrm{DW}$ & & \\
\hline \multirow[b]{3}{*}{ Cobb } & \multicolumn{12}{|c|}{ Unweighted von Bertalanffy } \\
\hline & \multirow[b]{2}{*}{99.77} & \multirow[b]{2}{*}{99.79} & & & & & & & & & & $*$ \\
\hline & & & 59.16 & 67.38 & 444.1 & 458.1 & 0.752 & 0.249 & $*$ & 0.996 & $*$ & $*$ \\
\hline Ross & 0080 & 0084 & 1565 & 6077 & 41106 & 146 & & & & & $*$ & * \\
\hline Ross & 99.88 & 99.84 & 45.65 & 60.77 & 416.06 & 446.90 & 0.005 & 0.995 & 0.700 & 0.300 & * & ${ }^{*}$ \\
\hline & & & & & & & & & & & * & * \\
\hline Hubbard & 99.77 & 99.78 & 61.63 & 68.20 & 448.48 & 459.42 & 0.555 & 0.445 & 0.319 & 0.682 & ${ }^{*}$ & ${ }^{*}$ \\
\hline & & & & & & eighted $v$ & Bertalan & & & & & \\
\hline Cobb & 99.68 & 99.66 & 2.293 & 1.953 & 93.01 & 75.71 & & & & & ** & ** \\
\hline & & & & & & & $* *$ & 1.000 & ** & 1.000 & & \\
\hline Ross & 9986 & 9966 & 1881 & 2103 & 7161 & 8369 & & & & & $* *$ & $* *$ \\
\hline Kuss & 99.00 & 99.00 & 1.001 & 2.105 & 11.01 & 05.09 & $* *$ & 1.000 & ** & 1.000 & & \\
\hline Hubbard & 9980 & 9970 & 1977 & 1713 & 7699 & 6150 & & & & & $* *$ & $* *$ \\
\hline Hubbard & 99.80 & 99.10 & 1.911 & $1 . / 13$ & 10.99 & 61.50 & $* *$ & 1.000 & $* *$ & 1.000 & w & $F^{n}$ \\
\hline & & & & & $\mathrm{AR}$ & )-weight & on Bert & & & & & \\
\hline & & & & & & & & & & & & \\
\hline Cobb & 99.85 & 99.83 & 1.560 & 1.381 & 55.25 & 38.50 & 0.738 & 0.262 & 0.989 & $*$ & $* *$ & $*$ \\
\hline Ross & 0905 & 0070 & 152 & 1640 & 5517 & 4442 & & & & & $*$ & $*$ \\
\hline Koss & 99.95 & 99.19 & 1.152 & 1.640 & 53.11 & 44.42 & 0.970 & $*$ & 0.991 & * & * & $*$ \\
\hline & & & & & & & & & & & * & \\
\hline Hubbard & 99.89 & 99.80 & 1.444 & 1.390 & 47.04 & 45.39 & 0.581 & 0.419 & 0.746 & 0.254 & $*$ & 0.563 \\
\hline & & & & & & Unweigh & Richard & & & & & \\
\hline & & & & & & & & & & & * & $*$ \\
\hline Cobb & 99.77 & 99.79 & 58.86 & 67.81 & 444.8 & 460.1 & 0.750 & 0.250 & $*$ & 0.997 & $*$ & $*$ \\
\hline Ross & 9988 & 9985 & 4577 & 6030 & 41760 & 44739 & & & & & * & $*$ \\
\hline Ross & 99.88 & 99.85 & 45.11 & 60.30 & $41 / .60$ & $44 / .39$ & $*$ & 0.997 & 0.728 & 0.272 & & \\
\hline Hubbard & 9976 & 9980 & 6222 & 6545 & 45078 & 45624 & & & & & * & $* *$ \\
\hline Huboard & 99.10 & 99.80 & 02.22 & 03.45 & 450.18 & 450.24 & 0.505 & 0.495 & 0.612 & 0.388 & & 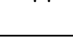 \\
\hline & & & & & & Weighte & ichards & & & & & \\
\hline & & & & & & & & & & & & \\
\hline Cobb & 99.86 & 99.89 & 1.553 & 1.114 & 52.21 & 16.27 & $* *$ & 1.000 & * & 0.970 & 0.168 & 0.942 \\
\hline Ross & 99.94 & 99.92 & 1.209 & 1.050 & 25.16 & 9.93 & & & & & 0.462 & 0.914 \\
\hline & & & & & & & $*$ & 1.000 & 0.762 & 0.238 & & \\
\hline Hubbard & 99.92 & 99.88 & 1.222 & 1.071 & 26.30 & 12.10 & & & & & 0.437 & 0.732 \\
\hline & & & & & & 12.10 & * & 0.983 & 0.393 & 0.607 & 0.451 & \\
\hline & & & & & & (1)-wei & ed Richa & & & & & \\
\hline & & & & & & & & & & & & \\
\hline Cobb & 99.89 & 99.89 & 1.371 & 1.101 & 40.04 & 16.35 & 0.700 & 0.300 & 0.445 & 0.555 & 0.407 & 0.900 \\
\hline Ross & 99.95 & 99.92 & 1.097 & 1.040 & 16.02 & 10.25 & 2 & & & & 0.110 & 0.750 \\
\hline & & & & & & & 0.400 & 0.600 & 0.088 & 0.912 & & \\
\hline Hubbard & 99.93 & 99.88 & 1.201 & 1.082 & 25.82 & 14.53 & & & & & 0.514 & 0.963 \\
\hline Huboard & 99.93 & 99.88 & 1.201 & 1.082 & 25.82 & 14.53 & 0.338 & 0.662 & 0.392 & 0.608 & 0.314 & 0.903 \\
\hline
\end{tabular}

* and **Significant at 0.5 and $0.1 \%$ probability, respectively. 
Table 8. Delta $(\Delta)$ values and Akaike weight (p) when comparing growth models, regarding body weight in Cobb, Ross, and Hubbard female and male broiler chickens.

\begin{tabular}{|c|c|c|c|c|}
\hline \multirow{3}{*}{ Line } & \multicolumn{4}{|c|}{$\Delta ;\left(\mathrm{p}_{\mathrm{b}}: \mathrm{p}_{\mathrm{a}}\right)^{(1)}$} \\
\hline & \multicolumn{2}{|c|}{ Gompertz P with AR (1) - Gompertz P } & \multicolumn{2}{|c|}{ Richards P with AR(1) - Richards P } \\
\hline & Female & Male & Female & Male \\
\hline Cobb & $-20.77 ;(1.0)$ & $-5.49 ;(0.9396: 0.0604)$ & $-12.2 ;(0.9977: 0.0023)$ & $0.08 ;(0.4896: 0.5104)$ \\
\hline Ross & $-32.57 ;(1.0)$ & $2.12 ;(0.2571: 0.7429)$ & $-9.1 ;(0.9897: 0.0103)$ & $0.32 ;(0.4603: 0.5397)$ \\
\hline \multirow[t]{3}{*}{ Hubbard } & $-24.43 ;(1.0)$ & $0.39 ;(0.4512: 0.5488)$ & $-0.5 ;(0.5594: 0.4406)$ & $2.43 ;(0.2285: 0.7715)$ \\
\hline & \multicolumn{4}{|c|}{ Richards models vs Gompertz models } \\
\hline & \multicolumn{2}{|c|}{ Female } & \multicolumn{2}{|c|}{ Male } \\
\hline Cobb & \multicolumn{2}{|c|}{$-2.96 ;(0.8145: 0.1855)^{(2)}$} & \multicolumn{2}{|c|}{$-5.32(0.9347: 0.0653)^{(3)}$} \\
\hline Ross & \multicolumn{2}{|c|}{$-19.40(0.9999: 0.0001)^{(2)}$} & \multicolumn{2}{|c|}{$-3.66(0.9474: 0.0526)^{(4)}$} \\
\hline Hubbard & \multicolumn{2}{|c|}{$-12.92(0.9984: 0.0016)^{(2)}$} & \multicolumn{2}{|c|}{$-8.97(0.9908: 0.0092)^{(4)}$} \\
\hline
\end{tabular}

${ }^{(1)} \Delta$, difference between AICc weights; $\left(\mathrm{p}_{\mathrm{b}} \mathrm{p}_{\mathrm{a}}\right)$, Akaike weight of the b model: Akaike weight of the a model. ${ }^{(2)}$ Akaike weight of the weighted Richards model (P) with AR (1) vs. weighted Gompertz model (P) with AR (1). ${ }^{(3)}$ Akaike weight of the weighted Richards model (P) vs. weighted Gompertz model (P) with AR (1). ${ }^{(4)}$ Akaike weight of the weighted Richards model (P) vs. weighted Gompertz model (P).

\section{Conclusions}

1. The incorporation of weighting and AR (1) weighting structures into growth models modifies the values of the parameters, and hampers the approximation of the autocorrelation parameter, showing that attention regarding statistical assumptions is necessary.

2. The weighted and AR (1)-weighted Richards models show optimal properties in model selection for males and females, respectively.

\section{Acknowledgments}

To Coordenação de Aperfeiçoamento de Pessoal de Nível Superior (Capes), for scholarship granted.

\section{References}

AGGREY, S.E. Logistic nonlinear mixed effects model for estimating growth parameters. Poultry science, v.88, p.276-280, 2009. DOI: $10.3382 /$ ps.2008-00317.

BRASIL. Lei ${ }^{\circ} 11.794$, de 8 de outubro de 2008. Regulamenta o inciso VII do $\S 1^{\circ}$ do art. 225 da Constituição Federal, estabelecendo procedimentos para o uso científico de animais; revoga a Lei $\mathrm{n}^{\circ}$ 6.638 , de 8 de maio de 1979; e dá outras providências. Diário Oficial da União, 9 out. 2008. Seção 1, p.1-2.

DRUMOND, E.S.C.; GONÇALVES, F.M.; VELOSO, R. de C.; AMARAL, J.M.; BALOTIN, L.V.; PIRES, A.V.; MOREIRA, J. Curvas de crescimento para codornas de corte. Ciência Rural, v.43, p.1872-1877, 2013. DOI: 10.1590/S0103-84782013001000023.

ELEROĞLU, H; YILDIRIM, A.; SEKEROĞLU, A.; ÇOKSÖYLER, F.N.; DUMAN, M. Comparison of growth curves by growth models in slow-growing chicken genotypes raised the organic system. International Journal of Agriculture and Biology, v.16, p.529-535, 2014.

FITZHUGH JR., H.A. Analysis of growth curves and strategies for altering their shape. Journal of Animal Science, v.42, p.10361051, 1976. DOI: 10.2527/jas1976.4241036x.

FREITAS, A.R. de. Curvas de crescimento na produção animal. Revista Brasileira de Zootecnia, v.34, p.786-795, 2005. DOI: 10.1590/S1516-35982005000300010.

GBANGBOCHE, A.B.; GLELE-KAKAI, R.; SALIFOU, S.; ALBUQUERQUE, L.G.; LEROY, P.L. Comparison of non-linear growth models to describe the growth curve in West African Dwarf sheep. Animal, v.2, p.1003-1012, 2008. DOI: 10.1017/ S1751731108002206.

HARRING, J.R.; BLOZIS, S.A. Fitting correlated residual error structures in nonlinear mixed-effects models using SAS PROC NLMIXED. Behavior Research Methods, v.46, p.372-384, 2014. DOI: 10.3758/s13428-013-0397-z.

MAZUCHELI, J.; SOUZA, R.M. de; PHILIPPSEN, A.S. Modelo de crescimento de Gompertz na presença de erros normais heterocedásticos: um estudo de caso. Revista Brasileira de Biometria, v.29, p.91-101, 2011.

MOHAMMED, F.A. Comparison of three nonlinear functions for describing chicken growth curves. Scientia Agriculturae, v.9, p.120-123, 2015.

MOTA, L.F.M.; ALCÂNTARA, D.C.; ABREU, L.R.A.; COSTA, L.S.; PIRES, A.V.; BONAFÉ, C.M.; SILVA, M.A.; PINHEIRO, S.R.F. Crescimento de codornas de diferentes grupos genéticos por meio de modelos não lineares. Arquivo Brasileiro de Medicina Veterinária e Zootecnia, v.67, p.1372-1380, 2015. DOI: 10.1590/1678-4162-7534.

MOTULSKY, H.; CHRISTOPOULOS, A. Fitting models to biological data using linear and nonlinear regression: a practical guide to curve fitting. San Diego: GraphPad Software, 2003. 351p.

Pesq. agropec. bras., Brasília, v.52, n.12, p.1241-1252, dez. 2017 DOI: 10.1590/S0100-204X2017001200013 
PRADO, T.K.L. do; SAVIAN, T.V.; MUNIZ, J.A. Ajuste dos modelos Gompertz e Logístico aos dados de crescimento de frutos de coqueiro anão verde. Ciência Rural, v.43, p.803-809, 2013. DOI: $10.1590 / \mathrm{S} 0103-84782013005000044$.

ROSTAGNO, H.S (Ed.). Tabelas brasileiras para aves e suínos: composição de alimentos e exigências nutricionais. 3.ed. Viçosa: Ed. da UFV, 2011. 252p.

SILVA, F. de L.; ALENCAR, M.M. de; FREITAS, A.R. de; PACKER, I.U.; MOURÃO, G.B. Curvas de crescimento em vacas de corte de diferentes tipos biológicos. Pesquisa Agropecuária Brasileira, v.46, p.262-271, 2011. DOI: 10.1590/ S0100-204X2011000300006.

THOLON, P.; PAIVA, R.D.M.; MENDES, A.R.A.; BARROZO, D. Utilização de funções lineares e não lineares para ajuste do crescimento de bovinos Santa Gertrudis, criados a pasto. ARS Veterinária, v.28, p.234-239, 2012.
THORNLEY, J.H.M.; FRANCE, J. Mathematical models in agriculture: quantitative methods for the plant, animal and ecological sciences. $2^{\text {nd }}$ ed. Wallingford: CABI Publishing, 2007. 928p.

TOMPIĆ, T.; DOBŠA, J.; LEGEN, S.; TOMPIĆ, N.; MEDIĆ, H . Modeling the growth pattern of in-season andoff-season Ross 308 broiler breeder flocks. Poultry Science, v.90, p.2879-2887, 2011. DOI: 10.3382/ps.2010-01301.

YANG, Y.; MEKKI, D.M.; LV, S.J.; WANG, L.Y.; YU, J.H.; WANG, J.Y. Analysis of fitting growth models in Jinghai mixedsex Yellow chicken. International Journal of Poultry Science, v.5, p.517-521, 2006. DOI: 10.3923/ijps.2006.517.521.

ZUIDHOF, M.J.; SCHNEIDER, B.L.; CARNEY, V.L.; KORVER, D.R.; ROBINSON, F.E. Growth, efficiency, and yield of commercial broilers from 1957, 1978, and 2005. Poultry Science, v.93, p.2970-2982, 2014. DOI: 10.3382/ps.2014-04291.

Received on July 19, 2016 and accepted on March 15, 2017 